ROCZNIKI NAUK SPOŁECZNYCH

Tom 13(49), numer 3 - 2021

DOI: https://doi.org/10.18290/rns21493.4

ANURADHA IDDAGODA

\title{
TOWARDS AN INSTRUMENT OF MEASURING THE CONSTRUCT OF LEADERSHIP BY THE 10 Cs FOR EMPLOYEE ENGAGEMENT
}

\section{INTRODUCTION}

Failures are inevitable on the road of organizational success and there the leader play a vital role in order to convert the failure to a lesson learned to the success. A "leader," as defined in the Pocket Oxford English Dictionary (2007), is a "person or thing that leads and as a person or thing that is the most successful or advanced in a particular area." Maccoby (2007) answers his own rhetorical question: "Who are the leaders we need?" saying that "they are the leaders motivated to achieve the common good and have the qualities required to gain the willingness of the followers in a particular culture, at a historical moment, when leadership becomes essential to meet the challenges of that time and place." The ability to deal with his/her employees for the purpose of reaching their full potential, unveiling their hidden talent and maximizing their financial performance are some of the key abilities a leader should possess. Truss et al. (2013) state that leaders are capable of inspiring employees and, just as they can enhance performance, they are also in a position to impact employee engagement. As mentioned by Opatha (2010), it is also essential that a leader should have a good personal character.

It is evident that in the past few decades business environments have become more complex and uncertain and therefore the leader has to play a vital role (Hysa et al., 2020; Maheshwari, Yadav, 2019; Dewasiri, Banda, 2015; Basri, Siam, 2019). Leader should maintain high level of virtues in-order to be credible. The origin of 'virtue' is the Latin virtus, which means 'strength' or 'skill'

ANURADHA IDDAGODA, PhD—Senior Lecturer, University of Sri Jayewardenepura, Sri Lanka; address for correspondence: Management Sciences Unit, Department of Mathematics, Faculty Applied Sciences, University of Sri Jayewardenepura, Gangodawila, Nugegoda, Sri Lanka; e-mail: anuradhaiddagoda@sjp.ac.lk; ORCID: https://orcid.org/0000-0003-2586-430X. 
(Nowakowski, 2015). Gardner (1990) refers to the two most crucial tasks within the popular concept that "leadership is motivation and goal setting." Leaders should create trust and confidence in a company by being exemplars of high ethical and performance standards in a blame-free context considering the components of psychological safety (Seijts, Crim, 2006; Xu, Thomas, 2011). These are the conditions proposed by Kahn (1990) which lead to employee engagement. In addition, Macey and Schneider (2008) state that job resources, job demands and leadership also make an important contribution when it comes to engaging employees. A theoretical discourse on leadership has evolved, about which Papalexandris and Galanaki (2009) state:

Such theories are Charismatic Leadership (R. J. House, 1977), Transformational Leadership (Bass, 1985), Visionary Leadership (Westley \& Mintzberg, 1998), Authentic Leadership (Luthans \& Avolio, 2003) and Shared Leadership (Ensley et al., 2003, p. 367).

Leadership is crucial for employee engagement, especially transformational leadership, empowering leadership and leader-member exchange (Bakker et al., 2011; Macey, Schneider, 2008). Transformational leaders offer a purpose that transcends short-term goals and focuses on higher order intrinsic needs. Transactional leaders, in contrast, focus on the proper exchange of resources.

The discourse on the concept of "employee engagement" is far rarer than the availability of discourse on it. Although a happy and contented employee is valued by any employer, attracting and retaining such happy and contented employees is a challenge for a business. One solution is the "engaging employee," which has become a buzz word in management circles (Iddagoda et al., 2016); employee engagement gives an organization a competitive edge (Bulińska-Stangrecka, Iddagoda, 2020). "Engaged employees" often tend to be loyal, innovative, creative and customer-oriented while being committed to maintaining a long-term relationship with the company (Iddagoda, Opatha, 2020; Bulińska-Stangrecka, Iddagoda, 2020). AON (2018) reveals that they do not hesitate to go the extra mile with the aim of achieving the organization's goals. Therefore as mentioned by Iddagoda and Opatha (2017) and Aldrin and Merdiaty (2019), employee engagement leads to employee job performance and organizational financial performance. The next question is how to achieve employee engagement. Leaders can play a huge role in achieving employee engagement. They can use the $10 \mathrm{Cs}$ formula for employee engagement suggested by Seijts and Crim (2006). 


\section{RESEARCH METHOD}

The archival method recommended by Tranfield et al. (2003) was mentioned in the literature review. The study is quantitative in nature. Full accounts of the conceptualization and operationalization of the employee engagement construct have been published in the study conducted by Iddagoda et al. (2016). Due to reasons of space the execution of conceptualization and operationalization of the construct of employee engagement is shown in Appendix. The research design is explained with the six components identified by Sekaran and Bougie (2010). The study mainly incorporates two theories in deriving the theoretical assertions, i.e., agency theory and social exchange theory. The purpose of the study is explanatory or hypothesis-testing. The time horizon of the study is cross-sectional. Correlational data come under the type of investigation collected through a survey of managerial employees. The extent of the researcher's interference with the study is minimal because the study setting is non-contrived. The unit of analysis is the individual. A self-administered questionnaire was conceptualized to collect data and a Likert scale as a five-point scale, i.e., strongly agree, agree, neutral, disagree and strongly disagree. Non-probability sampling was the sampling technique. The sample consisted of 272 persons from a population of 614 and the response rate was $52 \%$. Roscoe (1975), as cited in Sekaran (2003), advocated that the sample size should be larger than 30 and less than 500. The Statistical Package for Social Science was used for the analysis.

\section{EMPLOYEE ENGAGEMENT}

Iddagoda at al. (2016) defined employee engagement as the extent to which an employee gets involved in the job and the organization cognitively, emotionally and behaviorally. The view of Alqarni (2016) is that the concept of employee engagement has just become visible in the literature on organizational psychology, human resource management, and business management, and is associated with proven organizational results of several studies. According to Shuck et al. (2014), employees are likely to be engaged because of the message of value and support communicated by the ability to attend and participate. There the leader can play a huge role in order to enhance the level of employee engagement. 


\section{RELATIONSHIP BETWEEN LEADERSHIP AND EMPLOYEE ENGAGEMENT}

Several researches have been conducted on transformational leadership. Judge and Piccolo (2004), point out that while the result of transformational leadership is that followers recognize the leader's need, in the case of the transactional leader, he provides the followers something they want in exchange for something the leader wants. Avery (2004), as cited in Zhang et al. (2014), state that the visionary leader (also known as "transformational" or "charismatic") adds a future dimension to leadership and requires the emotional involvement of staff. Working through higher-order purposes that appeal to followers' needs and motives is commonly observed among visionary leaders. It is evident that in engaging employees a leader must be aware of the motives of employees' and their needs. The fact that motives and needs are balanced between individuals and teams is well known among leaders. Motives give a cue to the leader about what drives their employees. The Leader Member Exchange (LMX) theory, as Winkler (2010) points out, conceptualizes leadership as a process of interaction between leader and follower which is established on the dyadic relationships between both. Christian et al. (2011) discovered that transformational leadership and leader-member exchange are positively related to employee engagement.

As Carmeli et al. (2009) found, the participatory decision making process among top management teams is positively associated with decision effectiveness and the firm's performance. However, Carmeli et al. further state that positive outcomes can only be observed when the CEO or the leader welcomes a participatory role. A leader encouraging employees to be involved in attaining organizational goals promotes an autonomous work environment. Carmeli et al. (2009) provide an insight into the view of Seijts and Crim (2006) that the employees' value has control over the flow and pace of their jobs, and leaders are capable of creating opportunities for employees to exercise this particular control. At this juncture, the leader has to set the boundaries with the employees. The leader must consider setting the boundaries of activities with the involvement of employees and with appropriate arrangements so that they too can contribute to the decision making process. Explaining this concept, Seijts and Crim (2006) discuss how the feeling of "being in on things," and of "being given openings" to participate in decision making often reduce stress while creating trust and a culture in which people are willing to be personally involved and engaged in problems and their solutions. As suggested 
by $\mathrm{Xu}$ and Thomas (2011), leaders whose main concern is reaping the benefits of employee engagement should be primarily concerned with team building, developing a genuine interest in the personal development of team members and celebrating the achievements of the team.

Two leadership dimensions that have a significant influence on employee engagement have been identified by Papalexandris and Galanaki (2009), namely, (a) being a good manager or a mentor and (b) articulating vision. Seijts and Crim (2006) too hold a similar view; in their opinion, "clarity" emphasizes the importance of the leader communicating a clear vision. The vision or goal of the senior leadership and departmental heads for the organization, division, unit, or team is recognized as one major concern of the employees. Seijts and Crim further explain that employees demand awareness of the importance of organizational goals as well as the most appropriate way to achieve them. Seijts and Crim evidently consider vigilance, vision, mission, strategies and priorities among employees about what they do and why they do it/them. Dharmasiri (2011) explains this by quoting the famous story of how a minor worker answered President Kennedy in the NASA complex. During the late sixties when the popular "moon missions" were in operation, President Kennedy who visited NASA complex took a minute to ask a minor worker sweeping the floor what she was doing. She came up with an impressive answer; "I am helping to send a man to the moon." This can be held as a case of establishing a clear organizational vision. According to Seijts and Crim (2006), by exemplifying high ethical and performance standards, good leaders set the ground for building confidence in an organization. Seijts and Crim attribute this initiative to a "C" known as "Confidence." According to Dharmasiri (2011), one of the possible systems that a leader can put into practice is "walking the talk;" one's deeds being what (s)he says. This enables the employees to place greater trust and confidence in their leaders.

Saks and Gruman (2014) suggest three types of leadership with the aptitude to influence employee engagement through psychological conditions, job resources and job demands. The three types are transformational, empowering and leader-member exchange. Hogan and Kaiser (2005) opine that good leadership promotes effective team performance, which, in turn, improves the well-being of the incumbents. Seijts and Crim's (2006) view is that good leaders consistently attempt to develop employee skills and create small wins, which will help the team, unit or organization to perform at their best. Hogan and Kaiser (2005) argue that bad leaders degrade the quality of life of 
everyone under them. Hogan and Kaiser (2005) further state that the bad leader is responsible for the deep unhappiness of those under him/her.

A Gallup poll of the levels of employee engagement around the world over a considerable number of years revealed that whoever is named as manager in an organization is one of the most important decision makers, whose decisions play a significant role in enhancing employee engagement. According to Gallup (2013a), a great manager engages his/her employees in many ways, with genuine care and concern for his/her employees. By building strong, trusting relationships with their staff members, the manager can stimulate a positive and open work environment so that his/her employees sense a notion of support and engagement. As the report of Gallup (2013a) states, great managers care about individual performance while investing in talent.

In a sample of 1,003 employees in the United States of America (USA), Gallup (2013b) conducted a study to test the effects of the manager's approach on employee engagement and strength. It revealed that one quarter $(25 \%)$ of American workers fell into the ignored category, and $40 \%$ of these employees were actively disengaged. This report further revealed that the managers who focused on their employees' weakness cut active disengagement roughly in half, to $22 \%$, proving that even negative attention is better than no attention at all in employees' eyes. Gallup (2013b) report also states that by contrasting, for the $37 \%$ who agreed that their supervisor focused on their strengths, active disengagement fell dramatically to $1 \%$.

Hewitt (2015) reveals that leadership is an employee engagement driver and that leaders are the ultimate creators of a culture of employee engagement. The reason is that they believe "leadership is what makes or breaks the projects." Two researchers of organizational behaviour, Seijts and Crim (2006), present interesting insights through the concept of the " $10 \mathrm{Cs}$ for employee engagement;" principally, the $10 \mathrm{Cs}$ for employee engagement revolve around what corporate leaders should do to strengthen employee engagement. Refer to Table 1. 
Table 1. Ten C's for Employee Engagement

\begin{tabular}{|l|l|}
\hline \multicolumn{1}{|c|}{$\begin{array}{l}\text { Leadership } \\
\text { characteristic }\end{array}$} & \multicolumn{1}{c|}{ Leadership focus } \\
\hline 1. Connect & $\begin{array}{l}\text { Leaders must show that they value employees because employee } \\
\text { engagement is a direct reflection of how employees feel about their } \\
\text { relationship with the boss. }\end{array}$ \\
\hline 2. Career & $\begin{array}{l}\text { Most people want to do new things in their jobs. Therefore leaders } \\
\text { should: } \\
\text { - Provide challenging and meaningful work with opportunities for } \\
\text { career. } \\
\text { - Hold people accountable for progress. } \\
\text { - Assign [stretch?] goals. } \\
\text { - Provide jobs enriched by duties and responsibilities. }\end{array}$ \\
\hline 3. Clarity & Leaders must communicate a clear vision. \\
\hline 4. Convey & $\begin{array}{l}\text { Leaders clarify their expectations about employees and provide } \\
\text { feedback on their functioning in the organization. }\end{array}$ \\
\hline 5. Congratulate & Leaders should give recognition, and they do so a lot. \\
\hline 6. Contribute & $\begin{array}{l}\text { Leaders help people to see and feel how they contribute to the } \\
\text { organization's success and future. }\end{array}$ \\
\hline 7. Control & $\begin{array}{l}\text { Leaders set the boundaries which cater to the needs of the } \\
\text { employees as well as of the organization. }\end{array}$ \\
\hline 10. Confidence & $\begin{array}{l}\text { Great leaders are team builders; they create an environment that } \\
\text { fosters trust and collaboration. So the leaders should be concerned } \\
\text { about building teams. }\end{array}$ \\
\hline exemplars of high ethical and performance standards. \\
\hline demonstrate high ethical standards.
\end{tabular}

Source adapted: Seijts and Crim (2006), Dharmasiri (2011). 


\section{CONCEPTUALIZATION OF THE CONSTRUCT OF LEADERSHIP}

\subsection{REVIEW OF LEADERSHIP DEFINITIONS}

Ledlow and Coppola (2011) state that numerous definitions and variations of definitions are found in the literature and provide a collection of leadership definitions [of other authors] in his book titled Leadership for Health Professionals as follows:

- Tannenbaum, Weschler and Massarik (1961) defined leadership as interpersonal influence, exercised in a situation and directed through the communication process, towards the attainment of a specified goal or goals.

- Stogdill (1974) stated that leadership is the initiation and maintenance of structure in expectation and interaction.

- Peter and Waterman (1982) defined leadership as guiding an organization toward success.

- Rauch and Behling (1984) suggested that leadership is the process of influencing the activities of an organized group toward goal achievement.

- Jacobs and Jacques (1990) stated that leadership is a process of giving purpose (meaningful direction) to collective effort and causing willing effort to be expended to achieve purpose.

- Yukl (1994) noted that most definitions of leadership reflect the assumption that it involves a social influence process whereby intentional influence is exerted by one person over other people to structure the activities and relationships in a group or organization.

Researchers like Ledlow and Coppola (2011) provided a new definition by integrating the above mentioned leadership definitions. "Leadership is the dynamic and active creation and maintenance of an organizational culture and strategic systems that focus the collective energy of both leading people and managing resources toward meeting the needs of the external environment utilizing the most efficient, effective and efficacious methods possible by moral means." Leadership, according to Tannenbaum et al. (1961), Rauch and Behling (1984), and Yukl (1994) is "influencing." Tannenbaum et al. (1961), Peter and Waterman (1982) and Jacobs and Jacques (1990) believe that one of the main components of leadership is guiding. Leaders should guide and influence their subordinates towards achieving the vision. The vision should be a shared vision to achieve which the leader should inspire. A working definition of leadership is given below. 


\subsection{LEADERSHIP — WORKING DEFINITION}

Leadership is inspiring, guiding and influencing people when it is necessary.

\section{OPERATIONALIZATION OF THE VARIABLE OF LEADERSHIP}

\subsection{DIMENSIONS OF LEADERSHIP}

Leadership, conceptualized as a system, basically consists of three dimensions: inspire, guide and influence.

\subsection{INSPIRE}

As Ledlow and Coppola (2011) mention, the responsibility of inspiring employees to be committed to the organization is on the leader's shoulders, and his inspiration, motivation, enthusiasm and excellent communication skills play a crucial role here. Leaders, as Ledlow and Coppola (2011) believe, communicate a vision so that the employees are able to assess how situations and things could be crucial. Several meanings are given in the Pocket Oxford English Dictionary (2007) for 'inspire.' One is, "fill[ing] someone with the urge to do something" and the other, "a person or thing that inspires." Under the 10 C's listed by Seijts and Crim (2006), the element of "inspire" includes collaborate, congratulate, contribute and connect. Employees, according to Seijts and Crim, believe that working as teams with the trust and cooperation of their team members is more efficient than with individuals and teams with weak relationships. They further state that great leaders become team builders when they build a nurturing environment that promotes collaboration and trust. The concept called "collaborate" is the eighth "C". "Congratulate," which is the fifth "C," according to Seijts and Crim, is where recognition is given to the employees by the exceptional leader.

The sixth "C," which is "Contribute," as Seijts and Crim point out, when people have the desire to understand that their input matters and that they are meaningfully contributing to the organization's success. Leaders must demonstrate that they value employees, under the first "C," "Connect," say Seijts and Crim. This dimension is measured with statements such as: (1) My leader is a team builder; (2) My leader gives recognition for my achievements in the organization; (3) My leader helps me to see and feel how they are contributing to the organization's success and future; (4) My leader shows that he/she values me as an employee. Table 2 elaborates on the elements and statements of the dimension called "inspire." 
Table 2. The elements and statements of the dimension called "Inspire"

\begin{tabular}{|l|l|}
\hline \multicolumn{1}{|c|}{ Element } & \multicolumn{1}{c|}{ Statement } \\
\hline Collaborate & My leader is a team builder. \\
\hline Congratulate & My leader gives recognition for my achievements in the organization. \\
\hline Contribute & $\begin{array}{l}\text { My leader helps me to see and feel how they are contributing to the } \\
\text { organization's success and future. }\end{array}$ \\
\hline Connect & My leader shows that he/she value me as an employee. \\
\hline
\end{tabular}

\subsection{GUIDE}

Guiding employees when necessary is the task of the leader. A "guide," according to the Pocket Oxford English Dictionary (2007), is "a person who advices or shows the way to other people." Elements of "guide" are: confidence, credibility, clarity, convey and career, which fall under the 10C's of Seijts and Crim. Good leaders help create confidence in a company by being exemplars of high ethical and performance standards is the view of Seijts and Crim in 2016. Leaders should strive to maintain a company's reputation and demonstrate high ethical standards (ibid.). "C" standing for "Credibility" encapsulates [compressed] this concept.

Seijts and Crim mention that clarity of purpose in the organization, its desired achievements, and as to how employees of the organization can contribute to achieve them, are vital. This third "C" called "Convey" (ibid.) indicating clarifying the leader's expectations of employees while providing feedback on their performance is the task of the leader. Thus, good leaders establish processes and procedures that enable people to master important tasks and support goal achievement.

That employees desire to be innovative is evident. Similarly, employees' career development matters as well. Seijts and Crim (2006), agreeing with this argument, state that leaders are responsible for providing challenging as well as meaningful work that has potential for career advancement. This comes under " $\mathrm{C}$ " for "Career." The dimension called guide is measured with statements such as: (1) my leader helps to create confidence in a company by being an exemplar of high ethical and performance standards; (2) My leader strives to maintain a company's reputation and demonstrate high ethical standards; (3) My leader communicates clearly the organizational vision; (4) My leader clarifies his/her expectations of me as an employee and provides 
feedback on my functioning in the organization; (5) My leader provides challenging and meaningful work with opportunities for career development. Table 3 elaborates on the elements and statements of the dimension called "Guide."

Table 3. The elements and statements of the dimension called "Guide"

\begin{tabular}{|l|l|}
\hline \multicolumn{1}{|c|}{ Element } & \multicolumn{1}{c|}{ Statement } \\
\hline Confidence & $\begin{array}{l}\text { My leader helps to create confidence in a company by being } \\
\text { exemplars of high ethical and performance standards. }\end{array}$ \\
\hline Credibility & $\begin{array}{l}\text { My leader strives (tries hard) to maintain a company's reputation } \\
\text { and demonstrate high ethical standards. }\end{array}$ \\
\hline Clarity & My leader communicates the clear organizational vision. \\
\hline Convey & $\begin{array}{l}\text { My leader clarifies his/her expectations on me as an employee and } \\
\text { provides feedback on my functioning in the organization. }\end{array}$ \\
\hline Career & $\begin{array}{l}\text { My leader provides challenging and meaningful work with } \\
\text { opportunities for career development. }\end{array}$ \\
\hline
\end{tabular}

\subsection{INFLUENCE}

Influence is one of the core constituents of leadership. The Pocket Oxford English Dictionary (2007) defines "influence" as "the capacity to have an effect on someone's beliefs or actions," which means a leader has control over his/her subordinates. On the seventh "C" (Control), Seijts and Crim (2006) state that employees value control over the flow and pace of their jobs, which enables the leader to create opportunities for them to exercise this control. "Influence" is measured with statements such as "My leader sets the boundaries which cater to the needs of the employees as well as the organization." Table 4 lists the elements and statements of "Influence."

Table 4. The elements and statements of the dimension called "Influence"

\begin{tabular}{|c|l|}
\hline Element & \multicolumn{1}{c|}{ Statement } \\
\hline Control & $\begin{array}{l}\text { My leader sets the boundaries which cater to the needs of the } \\
\text { employees as well as the organization. }\end{array}$ \\
\hline
\end{tabular}


Figure 1 shows the dimensions and elements of the variable of leadership. (D) stands for a dimension and (E) for an element of the variable of leadership.

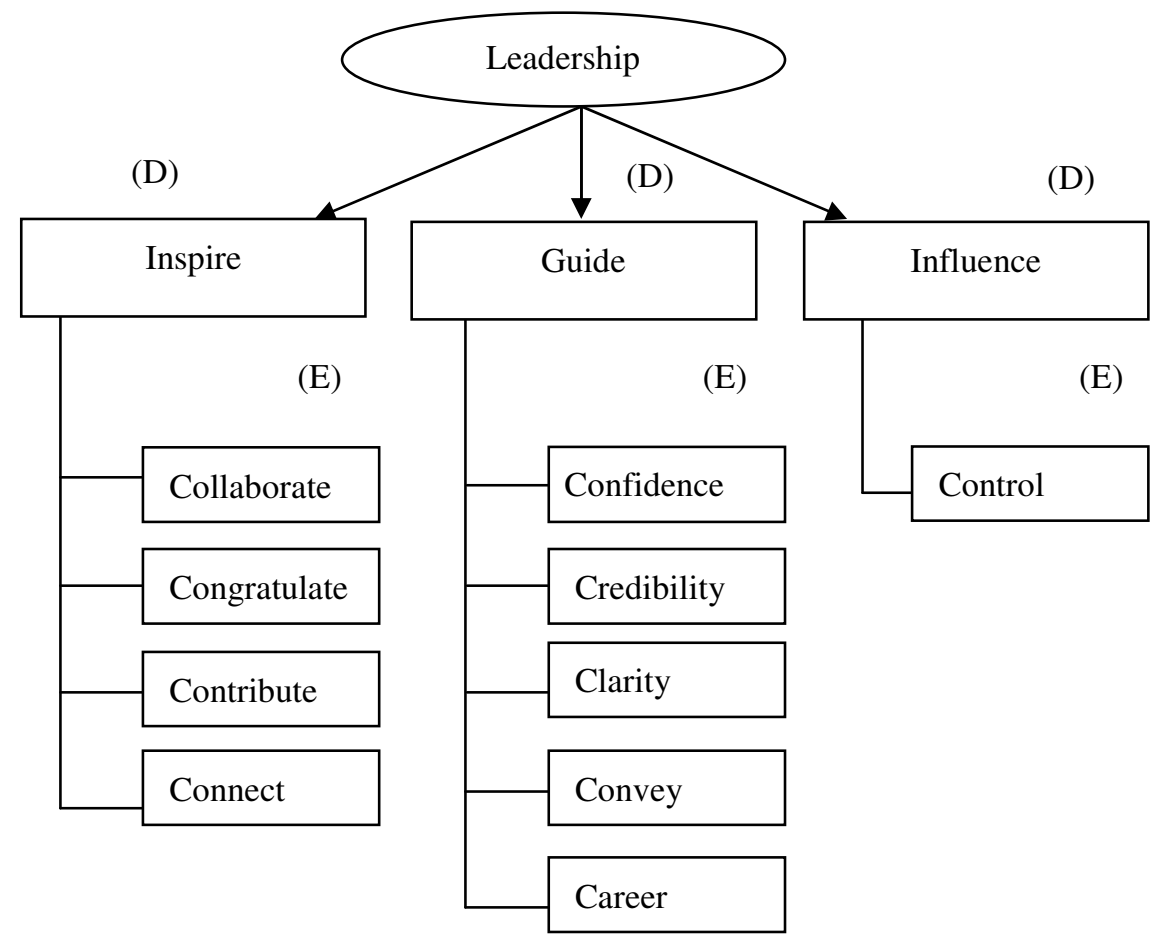

Figure 1. Dimensions and elements of the variable of leadership.

\section{RELIABILITY AND VALIDITY OF THE MEASUREMENTS}

The view of Sekaran and Bougie (2010) is that appropriate conceptualization and operationalization maintain content validity. Content validity of the instruments of this study is guaranteed through conceptualization and operationalization. The question statements were developed for each element of the dimension.

Exploratory factor analysis (EFA) was done to determine by the results of KMO and Bartlett's test of sphericity. Bartlett's test of sphericity is significant for the constructs of leadership and employee engagement. The survey results confirmed that both constructs correlate reasonably. Refer to Table 5. 
Table 5. KMO and Bartlett's test for the construct

\begin{tabular}{|l|l|r|r|}
\hline \multicolumn{2}{|c|}{} & Leadership & Employee engagement \\
\hline \multicolumn{2}{|l|}{ KMO measures of sampling adequacy } & 0.917 & 0.824 \\
\hline \multirow{3}{*}{$\begin{array}{l}\text { Bartlett's test } \\
\text { of sphericity }\end{array}$} & Approx. Chi ${ }^{2}$ & 1180.615 & 738.208 \\
\cline { 2 - 4 } & Df & 45 & 66 \\
\cline { 2 - 4 } & Sin & 0.000 & 0.000 \\
\hline
\end{tabular}

Inter-item consistency reliability, i.e., Cronbach alpha for the constructs of leadership and employee engagement were at a desirable level. According to Nunnally and Bernstein (1994), as cited in Andrew et al. (2019), Cronbach's alpha values at or above 0.7 are desirable. Refer to Table 6.

Table 6. Reliability test for the variables

\begin{tabular}{|l|r|}
\hline \multicolumn{1}{|c|}{ Variable } & Cronbach's alpha reliability coefficient $(\alpha)$ \\
\hline Leadership & 0.896 \\
\hline Employee engagement & 0.786 \\
\hline
\end{tabular}

\section{INTENSITY OR NATURE OF LEADERSHIP}

The variable of leadership is measured with 10 question items. The dimensions of this variable are inspire, guide and influence. There are 10 elements under these three dimensions (See Table 2, 3, and 4). The score of the construct of leadership will be in the range of 10 to 50 . This construct's levels between these limits can be shown in a continuum. Refer to Figure 2 and Figure 3 . The difference in the range of values can be reckoned as (50-10)/5 $=8$. For purposes of analysis, the values depicted in Figure 2 were transformed to new values. See Table 7.

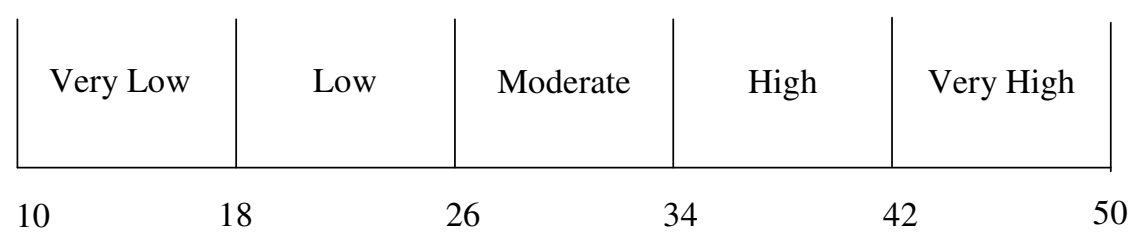

Figure 2. A continuum for leadership. 
Table 7. Transformation of the levels of leadership

\begin{tabular}{|l|c|c|}
\hline \multicolumn{1}{|c|}{ Scale } & Range of points & New values \\
\hline Very low & $10-18$ & 1 \\
\hline Low & $19-26$ & 2 \\
\hline Moderate & $27-34$ & 3 \\
\hline High & $35-42$ & 4 \\
\hline Very high & $43-50$ & 5 \\
\hline
\end{tabular}

Table 8. Descriptive statistics for the construct of leadership

\begin{tabular}{|l|c|c|c|c|c|}
\hline & $N$ & Minimum & Maximum & Mean & Std. deviation \\
\hline $\begin{array}{l}\text { Leadership } \\
\text { (Leader 5) }\end{array}$ & 272 & 1.00 & 5.00 & 4.319 & 0.701 \\
\hline
\end{tabular}

Source: Survey data

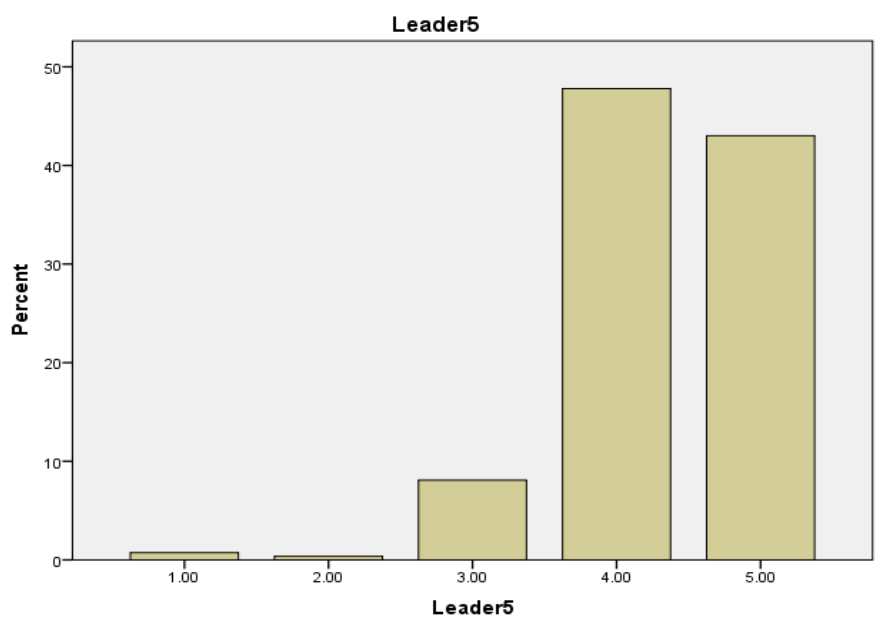

Figure 3. Histogram of descriptive statistics for leadership.

Source: Survey data 
The mean of 4.319 falls into the category of "high" level of leadership based on the data depicted in Table 8 and Figure 3. The standard deviation is 0.701 , which is small. The minimum is 1.00 , which means that the minimum level of leadership is "very low." The maximum is 5.00. Based on all this, the researchers can say the respondents answered within the range of very low to very high according to the descriptive statistics of "leadership." Most of the respondents "agreed" in the five-point Likert scale of the construct of leadership. Based on these findings it can be concluded that the intensity or nature of leadership is perceived highly by executives and managers in the Sri Lankan listed companies.

\section{LEADERSHIP AND EMPLOYEE ENGAGEMENT}

Gardner's (1990) view is that leadership is motivation and goal setting. Truss et al. (2013) also presented a similar view: leaders are capable of inspiring employees, and the ultimate result is enhancement of employee job performance. Eisenhardt (1989) mentions under Agency Theory, that agency relations are problematic to the degree that the principal and agent have inconsistent aims, and to monitor the agent's performance is difficult or expensive for the principal. The leader, at this point, becomes the principal. Seijts \& Crim (2006) elucidate what corporate leaders should do with the intention of strengthening employee engagement under their $10 \mathrm{Cs}$ of employee engagement. They state, under the second "C" called "Career," that most employees want to do innovative things in their jobs and how assigning stretch goals by leaders is essential. When it comes to the Social Exchange Theory, Homans (1958) presents an idea about social behaviour, which was founded on exchange. According to Homans (1958), the concept of exchange was not limited to material goods, and this, also includes symbolic values such as approval and reputation or esteem. Cropanzano and Mitchell (2005) suggest, via the Social Exchange Theory that an individual prefers to exchange the resources that are equal to the resources that (s)he has received. A stronger theoretical rationale that explains employee engagement, as Saks (2006) states, is found in the Social Exchange Theory. He further states that a strong theoretical justification has been laid down in the Social Exchange Theory to explain why the employee reacts to work-related resources that have varying levels of engagement. Seijts and Crim listed Connect, Career, Clarity, Convey, Congratulate, Contribute, Control, Collaborate, Credibility and Confidence as the $10 \mathrm{Cs}$ of employee engagement. These $10 \mathrm{Cs}$ point to what 
business leaders should practice in strengthening employee engagement. Anitha (2014) reveals the impact of employee engagement on employee job performance. According to Harter et al. (2002), employee engagement leads to high levels of organizational financial performance. Researchers like AON (2018), Christian et al. (2011), Xu and Thomas (2011), Papalexandris and Galanaki (2009), Seijts and Crim (2006), have ascertained a positive relationship between leadership and employee engagement. Refer to Figure 4.

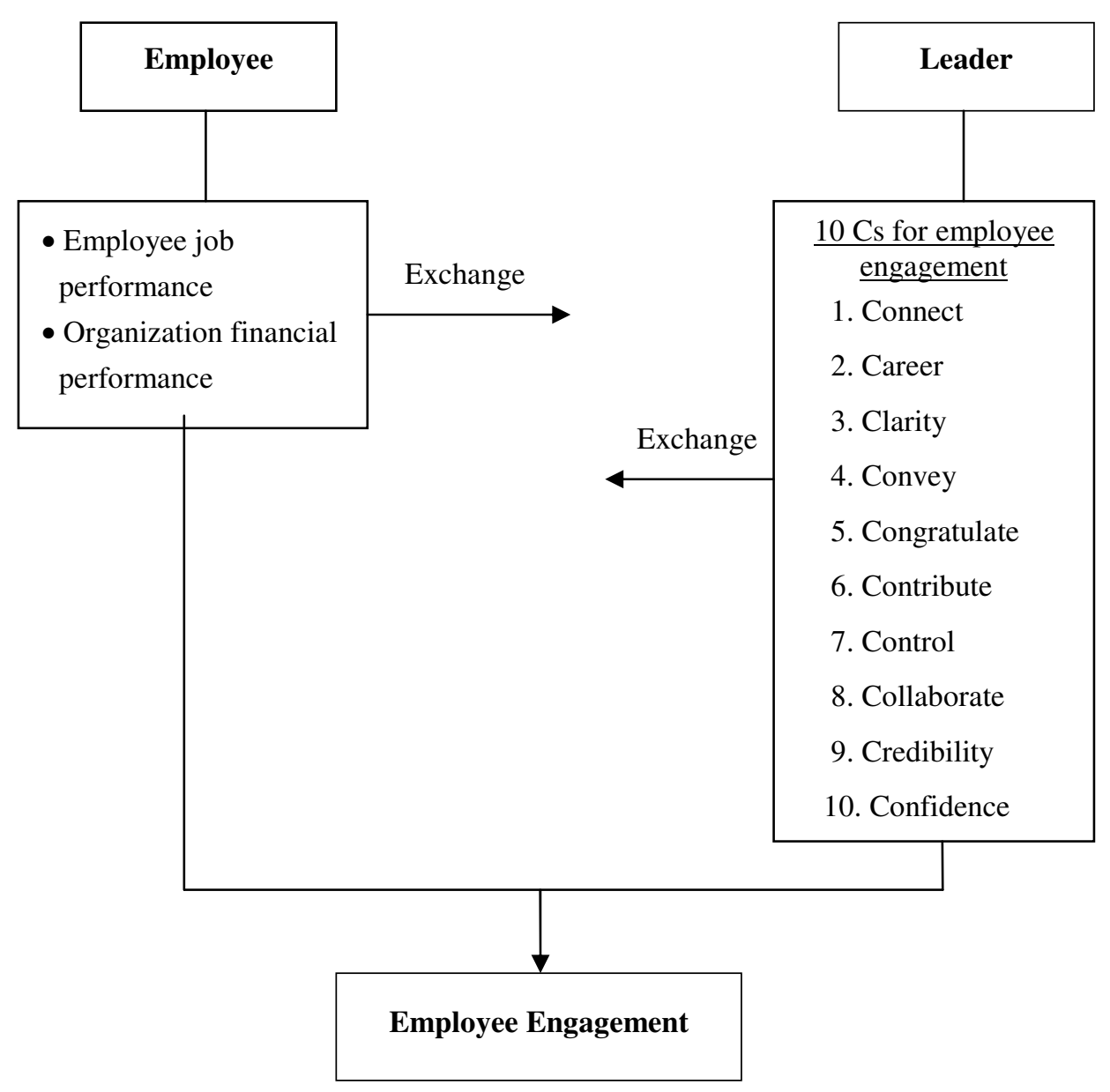

Figure 4. Theoretical assertions derived from social exchange theory. 
The influence of leadership on employee engagement leads to the following hypothesis:

Hypothesis 1: The higher the leadership, the higher the employee engagement. Testing H1

The investigation of the Pearson correlation matrix of the variables is shown in Table 3. A one-tailed test was conducted in order to test the non-directional hypothesis. When the leadership level is high, the level of employee engagement should be high since this is a bivariate hypothesis. Leadership and employee engagement are highly correlated with a coefficient of $0.220^{* *}$. Refer to Table 9. The relationship between leadership and employee engagement is highly significant at the level of 0.01 . The null hypothesis is rejected since there is a significant correlation between leadership and employee engagement.

Table 9. Correlation for leadership and employee engagement

\begin{tabular}{|l|l|r|}
\hline \multicolumn{2}{|c|}{} & \multicolumn{2}{|c|}{ Leader 5 } \\
\hline \multirow{2}{*}{ Eng 5 } & Pearson Correlation & $0.220^{* *}$ \\
\cline { 2 - 3 } & Sig. (1-tailed ) & 0.000 \\
\cline { 2 - 3 } & $N$ & 272 \\
\hline
\end{tabular}

\section{DISCUSSION}

Saks and Gruman (2014) point out ambiguities still present about the concept of employee engagement despite many researches. Statistics show that there is still a crisis of employee engagement. Gallup which is a survey organization revealed in 2017 that $31 \%$ of employees are engaged in Northern American (USA and Canada). This is the world's highest employee engagement rate recorded. In South Asia, according to Gallup (2017) the employee engagement level is $14 \%$ and in Sri Lanka it is 38\%. Several researchers identified a link between leadership and employee engagement. Seijts and Crim (2006) are among them. Leaders cannot demand a high level of engagement from their employees while standing on the sidelines. Seijts and Crim (2006), through the ten C's of employee engagement unveil, what a leader should do in order to enhance the level of employee engagement. Therefore, the researchers of the study believe an instrument for measuring the construct of leadership should have the influence of the $10 \mathrm{Cs}$ of employee engagement. 


\section{Managerial Implications}

Leadership also helps enhance the level of employee engagement. This proves through this study as well since the relationship between the two constructs, i.e., leadership and employee engagement, is highly significant. Therefore the managerial employees as leaders should be concerned about the practices of enhancing employee engagement. One such set of practices is the 10 Cs of employee engagement presented by Seijts and Crim (2006).

\section{Research Limitations}

The prospective weaknesses of the study which are outside the control of the researcher are known as the limitations. This is a cross-sectional research study and it is the most noticeable limitation. According to Saunders et al. (2009), a cross-sectional study is a particular phenomenon (or phenomena) at a particular time, i.e., a "snap shot" and a longitudinal study as a study of a particular phenomenon (or phenomena) over an extended period of time. Due to time constraints the researchers of this study decided that the time horizon of this study should be cross-sectional. This is one reason. Another reason is, that it is a known fact that one of the important goals of any organization is profit making. For this reason management is reluctant to allow their employees to spend time answering the questionnaire several times.

\section{Future Research}

Longitudinal studies or field experiments also can be carried out since this study is only a cross-sectional study.

\section{CONCLUSION}

It is evident that leadership enhances the level of employee engagement. Therefore, executives and managers as leaders should be concerned about practices dealing with enhancing employee engagement. One such set of practices is the $10 \mathrm{Cs}$ of employee engagement. Leadership, conceptualized as a system, basically consists of three dimensions, namely, inspire, guide and influence. The validated and well adapted instrument for leadership is provided as a part of this study. The link between leadership and employee engagement has been strengthened by the Agency Theory, Social Exchange Theory and the evidence from literature. The relationship between the two constructs, namely, leadership and employee engagement, is highly significant. Based on the empirical evidence, it can be concluded that the intensity or nature of leadership is perceived highly by the managerial employees in the listed Sri Lankan companies. 


\section{REFERENCES}

Aldrin N., Merdiaty N. (2019), Effect of Job Crafting on Work Engagement with Mindfulness as a Mediator, Cogent Psychology, 6(1), pp. 1-14.

Alqarni S. A. Y. (2016), Quality of Work Life as a Predictor of Work Engagement Among the Teaching Faculty at King Abdulaziz University, International Journal of Humanities and Social Science, 6(8), pp. 118-135.

Andrew D. P., Pedersen P. M., McEvoy C. D. (2019), Research Methods and Design in Sport Management, Champaign: Human Kinetics.

Anitha J. (2014), Determinants of Employee Engagement and Their Impact on Employee Performance, International Journal of Productivity and Performance Management, 63(3), pp. 308-323.

AON, (2018), 2018 Trends in Global Employee Engagement, Retrieved June 12, 2019 from https://www.kincentric.com/-/media/kincentric/pdfs/kincentric_2019_trends_global_employee_ engagement.pdf.

Avery G. C. (2004), Understanding Leadership: Paradigms and Cases, London, Thousand Oaks: Sage.

Bakker A. B., Albrecht S. L., Leiter M. P. (2011), Work Engagement: Further Reflections on the State of Play, European Journal of Work and Organizational Psychology, 20(1), pp. 74-88.

Basri W. S. M., Siam M. R. (2019), Social Media and Corporate Communication Antecedents of SME Sustainability Performance: A Conceptual Framework for SMEs of Arab World, Journal of Economic and Administrative Sciences, 35(3), pp. 1-12.

Bass B. M. (1985), Leadership and Performance Beyond Expectations, New York: Free Press.

Bulińska-Stangrecka H., Iddagoda, Y.A. (2020), The Relationship Between Inter-Organizational Trust and Employee Engagement and Performance, Academy of Management, 4(1), pp. 8-25.

Carmeli A., Sheaffer Z., Halevi M. Y. (2009), Does Participatory Decision-Making in Top Management Teams Enhance Decision Effectiveness and Firm Performance?, Personnel Review, 38(6), pp. 696-714.

Christian M. S., Garza A. S., Slaughter J. E. (2011), Work Engagement: A Quantitative Review and Test of its Relations with Task and Contextual Performance, Personnel Psychology, 64(1), pp. 89-136.

Cropanzano R., Mitchell M. S. (2005), Social Exchange Theory: An Interdisciplinary Review, Journal of Management, 31(6), pp. 874-900.

De Vries D. (2012), Leveraging Patents Financially: A Company Perspective, Wiesbaden: Gabler; Springer Fachmedien Wiesbaden.

Dewasiri N. J., Banda Y. W. (2015), Dividend Policy and Stock Price Volatility: An Error Corrected Approach, Asia-Pacific Journal of Management Research and Innovation, 11(3), pp. 165-171.

Dharmasiri A. (2011), Engaging Employees Enthusiastically, Retrieved May 22, 2016 from http://www.ft.lk/article/57105/Engaging-employees-enthusiastically

Eisenhardt K. M. (1989), Agency Theory: An Assessment and Review, Academy of Management Review, 14(1), 57-74.

Ensley M. D., Pearson A., Pearce C. L. (2003), Top Management Team Process, Shared Leadership, and New Venture Performance: A Theoretical Model and Research Agenda, Human Resource Management Review, 13(2), pp. 329-346. 
Gallup, (2013a), State of the Global Workplace, Retrieved August 12, 2015 from: http://www.securex.be/export/sites/default/.content/download-gallery/nl/brochures/Gallup-stateof-the-GlobalWorkplaceReport_20131.pdf

Gallup, (2013b), State of the American Workplace Report, Retrieved August 12, 2015 from http://employeeengagement.com/wp-content/uploads/2013/06/Gallup-2013-State-of-the-AmericanWorkplace-Report.pdf.

Gallup, (2017), State of the Global Workplace, Retrieved October 25, 2019 from: http://www. managerlenchanteur.org/wp-content/uploads/Gallup-State-of-the-Global-Workplace-port2017_ Executive-Summary.pdf.

Gardner J. (1990), On Leadership, New York: Macmillan.

Hewitt A. (2015), 2015 Trends in Global Employee Engagement, Retrieved September 10, 2016 from: https://www.aon.com/attachments/human-capital-consulting/2015-Trends-in-Global-EmployeeEngagement-Report.pdf.

Hogan R., Kaiser R. B. (2005), What we Know About Leadership, Review of General Psychology, 9(2), p. 169-180.

Homans G. C. (1958), Social Behavior as Exchange, American Journal of Sociology, 63(6), pp. 597-606.

House R. J. (1977), A 1976 Theory of Charismatic Leadership, [in:] J. G. Hunt, L. L. Larson (Eds.), Leadership: The Cutting Edge, Carbondale: Southern Illinois University Press, pp. 189-207.

Hysa E., Kruja A., Rehman N. U., Laurenti R. (2020), Circular Economy Innovation and Environmental Sustainability Impact on Economic Growth: An Integrated Model for Sustainable Development, Sustainability, 12(12), pp. 1-16.

Iddagoda Y. A., Opatha H. H. D. N. P. (2017), Identified Research Gaps in Employee Engagement, International Business Research, 10(2), pp. 63-73.

Iddagoda Y. A., Opatha H. H. (2020), Relationships and Mediating Effects of Employee Engagement: An Empirical Study of Managerial Employees of Sri Lankan Listed Companies, SAGE Open, 10(2), pp. 1-22.

Iddagoda Y. A., Opatha H. H. D. N. P., Gunawardana K. (2016), Towards a Conceptualization and an Operationalization of the Construct of Employee Engagement, International Business Research, 9(2), pp. 85-98.

Jacobs T. O., Jaques E. (1990), Military Executive Leadership, [in:] K.E. Clark, M.B. Clark (Eds.), Measures of Leadership, West Orange: Leadership Library of America, pp. 281-295.

Judge T. A., Piccolo R. F. (2004), Transformational and Transactional Leadership: A Meta-Analytic Test of Their Relative Validity, Journal of Applied Psychology, 89(5), pp. 755-768.

Kahn W. A. (1990), Psychological Conditions of Personal Engagement and Disengagement at Work, Academy of Management Journal, 33(4), pp. 692-724.

Ledlow G. R., Coppola M. N. (2011), Leadership for Health Professionals: Theory, Skills, and Applications, Sudbury: Jones and Bartlett.

Luthans F., Avolio B. J. (2003), Authentic Leadership: A Positive Developmental Approach, [in:] K. S. Cameron, J. E. Dutton, R. E. Quinn (Eds.), Positive Organizational Scholarship: Foundations of a New Discipline, San Francisco: Barrett-Koehler, pp. 241-261.

Maccoby M. (2007), The Leaders we Need: And what Makes us Follow, Boston: Harvard Business School Press. 
Macey W. H., Schneider B. (2008), The Meaning of Employee Engagement, Industrial and Organizational Psychology, 1(1), pp. 3-30.

Maheshwari S. K., Yadav J. (2019), The Role of HR in Leadership Development, Development and Learning in Organizations: An International Journal, 33(5), pp. 20-23.

Nowakowski P.T. (2015), Virtues and Their Role in Education, Społeczeństwo i Rodzina, 42(1), pp. 7-21.

Nunnally J. C., Bernstein I. H. (1994), The Assessment of Reliability, Psychometric Theory, 3, pp. 248-292.

Opatha H. H. D. N. P. (2010), Personal Quality, Colombo: Department of Human Resource Management USJ.

Papalexandris N., Galanaki E. (2009), Leadership's Impact on Employee Engagement, Leadership \& Organization Development Journal, 30(4), p. 365-385.

Peters T. J., Waterman R. H. (1982), In Search of Excellence: Lessons from America's Best-Run Companies, New York: Harper \& Row.

Pocket Oxford English Dictionary. (2007), Oxford: Oxford University Press.

Rauch C. F., Behling O. (1984). Functionalism: Basis for an Alternate Approach to the Study of Leadership, [in:] J. G. Hunt, D. M. Hosking, C. A. Schriesheim, R. Stewart (Eds.), Leaders and Managers: International Perspectives on Managerial Behavior and Leadership, New York: Pergamon Press, pp. 45-62.

Saks A. M. (2006), Antecedents and Consequences of Employee Engagement, Journal of Managerial Psychology, 21(7), pp. 600-619.

Saks A. M., Gruman J. A. (2014), What do we Really Know About Employee Engagement?, Human Resource Development Quarterly, 25(2), pp. 155-182.

Saunders M. N. K., Lewis P., Thornhill A. (2009), Research Methods for Business Students, Harlow: Financial Times/Prentice Hall.

Seijts G. H., Crim D. (2006), What Engages Employees the Most or the ten C's of Employee Engagement, Ivey Business Journal, 70(4), pp. 1-5.

Sekaran U. (2003), Research Methods for Business: A Skill-Building Approach, New York: John Wiley \& Sons.

Sekaran U., Bougie R. (2010), Research Methods for Business: A Skill Building Approach, New York: John Wiley \& Sons.

Shuck B., Twyford D., Reio T. G. Jr., Shuck A. (2014), Human Resource Development Practices and Employee Engagement: Examining the Connection with Employee Turnover Intentions, Human Resource Development Quarterly, 25(2), pp. 239-270.

Stogdill R. M. (1974), Handbook of Leadership: A Survey of Theory and Research, New York: Free Press.

Tannenbaum R. J., Weschler I. R., Massarik F. (1961), Leadership and Organization: A Behavioral Science Approach, New York: MacGraw-Hill.

Tranfield D., Denyer D., Smart P. (2003), Towards a Methodology for Developing Evidence-Informed Management Knowledge by Means of Systematic Review, British Journal of Management, 14(3), pp. 207-222.

Truss C., Alfes K., Delbridge R., Shantz A., Soane E. (Eds.) (2013), Employee Engagement in Theory and Practice, London: Routledge. 
Westley F. R., Mintzberg H. (1988), Profiles of Strategic Vision: Levesque and Iacocca, [in:] J. A. Conger, R. N. Kanungo (Eds.), Charismatic Leadership: The Elusive Factor in Organizational Effectiveness, San Francisco: Jossey-Bass, pp. 161-212.

Winkler I. (2010), Contemporary Leadership Theories: Enhancing the Understanding of the Complexity, Subjectivity and Dynamic of Leadership, Heidelberg; New York: Physica-Verlag.

Xu J., Thomas H. C. (2011), How Can Leaders Achieve High Employee Engagement?, Leadership \& Organization Development Journal, 32(4), pp. 399-416.

Yukl G. (1994), Leadership in Organizations, Englewood Cliffs: Prentice-Hall International

\section{APPENDIX}

Conceptualization and operationalization of three variables published in three articles.

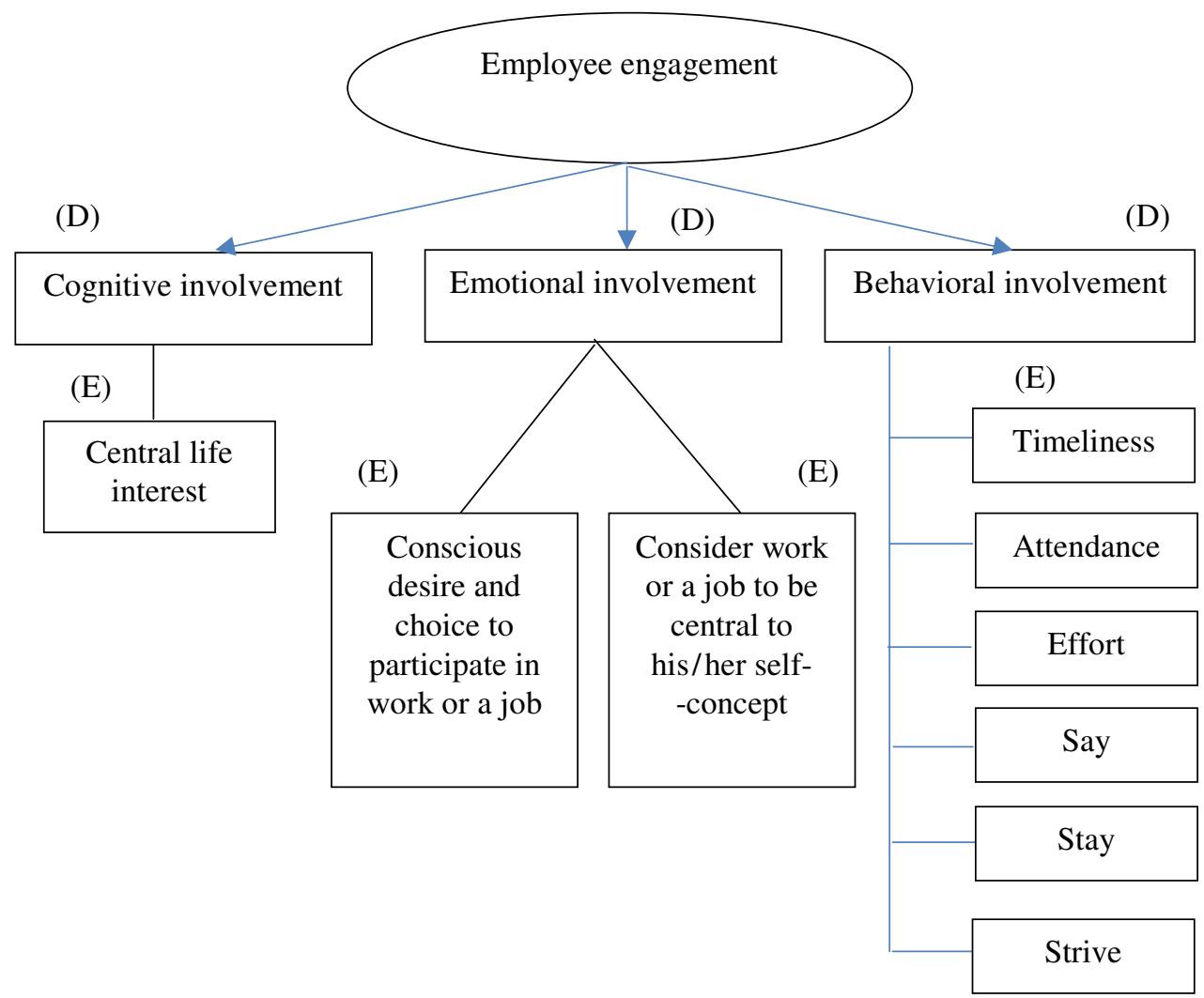

Figure 5. Dimensions and elements of the variable of employee engagement.

Source: Iddagoda et al. (2016). 


\title{
TOWARDS AN INSTRUMENT OF MEASURING \\ THE CONSTRUCT OF LEADERSHIP \\ BY THE 10 CS FOR EMPLOYEE ENGAGEMENT
}

\begin{abstract}
Summary
This paper seeks to operationalized the construct of leadership with the influence of $10 \mathrm{Cs}$ of employee engagement with the intention of measuring it. In addition, it addresses the intellectual curiosity to know the intensity of leadership of the managerial employees by using this instrument. The relationship between leadership and employee engagement is also examined. The archival method was used in the literature review. In order to analyze the data relating to 272 managerial employees, structural equation modeling was used. The construct of leadership operationalized using the $10 \mathrm{Cs}$ formula for employee engagement is suggested. The link between leadership and employee engagement is also identified based on the theoretical background and literature-based evidence. The study emphasizes the magnitude leadership instrument using the $10 \mathrm{Cs}$ formula for employee engagement in measuring the relationship between leadership and employee engagement.
\end{abstract}

Keywords: leadership; 10 Cs formula; conceptualization; operationalization.

\section{W POSZUKIWANIU NARZĘDZIA DO POMIARU KONSTRUKTU PRZYWÓDZTWA UWZGLĘDNIAJĄCEGO 10 CS ZAANGAŻOWANIA PRACOWNIKÓW}

\section{Streszczenie}

W artykule podjęto próbę operacjonalizacji konstruktu przywództwa z uwzględnieniem wpływu 10 Cs na zaangażowanie pracowników. Podjęto próbę jego pomiaru i zbadania siły przywództwa pracowników szczebla kierowniczego z wykorzystaniem tego instrumentu. Ukazano również zależność między przywództwem a zaangażowaniem pracowników. Przegląd literatury opiera się na metodzie archiwalnej. Do analizy danych dotyczących 272 pracowników szczebla kierowniczego zastosowano modelowanie równań strukturalnych. Zaproponowano konstrukt przywództwa zoperacjonalizowany za pomocą formuły $10 \mathrm{Cs}$ dla zaangażowania pracowników. Zidentyfikowano też związek między przywództwem a zaangażowaniem pracowników, opierając się na podstawach teoretycznych i badaniach przedstawionych w literaturze przedmiotu. Podkreślono znaczenie instrumentu przywództwa wielkościowego wykorzystującego formułę 10 Cs celem zaangażowania pracowników w przeprowadzenie badania związku między przywództwem a zaangażowaniem pracowników.

Słowa kluczowe: przywództwo; formuła 10 Cs; konceptualizacja; operacjonalizacja. 